\title{
Unified land use in the modern system of state cadastral registration
}

\author{
Yulia Golyakova ${ }^{1, *}$ \\ ${ }^{1}$ Industrial University of Tyumen, 38, Volodarsky St., Tyumen, 625000, Russia
}

\begin{abstract}
This paper discusses the features of such a unique land plot type as the unified land use. This type of a land plot appeared by virtue of the Russian Federal Law No. 28-FZ "On the State Land Cadastre" dated January 2, 2000. However, the current land legislation does not contain such a term. Currently, the unified land use cannot be formed, but previously registered land still exists in the state cadastre. In addition to a number of features in the land register procedure, the unified land use has no restrictions and freely participates in civilian circulation. Land plots that are the unified land use may be subject to all types of transformation specified in 11.9 of the Land Code of the Russian Federation, with the transformation into two types: the so-called ordinary plot and multicontour land plot. It should also be noted that there is no term of multicontour land plot in the land legislation. Some authors draw an analogy between the unified land use and a multi-contour land plot. However, there are a number of differences.
\end{abstract}

\section{Introduction}

Concept «Unified land use» appeared in land legislation due to the need for cadastral registration of several land plots, which by virtue of Article 134 of the Civil Code of the Russian Federation, are a complex thing. In accordance with the Federal Law of January 2, 2000 №28-Ф3 “On the State Land Cadastre”, which became invalid since May 17, 2008, when implementing state cadastral registration, the land plot consisting of separate parts was assigned to name «unified land use».

Under the single land use (hereinafter referred to as ULU) was meant a land plot consisting of several separate land plots with a single cadastral number, which was owned and used as a single property.

\section{Legal regulation}

Prior to the entry into force of the Rules for assigning cadastral numbers to land plots (clause 5), approved by the Decree of the Government of the Russian Federation of

\footnotetext{
*Corresponding author: goliakova84@mail.ru
} 
September 6, 2000 № 660, land legislation did not contain the concept of a land plot as a complex thing.

According to the specified paragraph, several separate land plots constituting a single land use, at the request of rightholder, could be taken into account as one real estate object by assigning it a cadastral number.

Order of Federal Land Cadastre Service of Russia № P / 119 of 15 June 2001 states that the land plots counted as real estate objects are assigned the name «land use». Composite land plots are given the name «Unified land use», and cadastral numbers.

Unified land use was a complex object, consisting of:

- «isolated plots» - plots divided among themselves by other plots or lands;

- «conditional plots» - adjacent plots, divided among themselves by the conditional line of cadastral division.

Figure 1 shows a single land use with cadastral number 72: 16: 0302001: 64, consisting of two separate plots with cadastral numbers 72: 17: 0302001: 66 and 72: 17: 0302001: 65, divided by other land plots, and lands that are not included in the composition of a single land uses. Which means that this land use is the so-called ordinary land plots.

Figure 2 shows a unified land use with cadastral number 72:16:0000000:308, consisting of two conditional plots with cadastral numbers 72:16:0104001:1 and 72:16:0107001:3, separated by a line of cadastral quarters. Which means that this land use is a regular land plot consisting of several adjacent plots.

All land plots bearing the status of a single land use are located in the so-called zero quarter. Special conditional cadastral quarters are created to account parcels, located in more than one cadastral quarter or district, significant for the length of a single land use:

-Inside every cadastral district - one conditional cadastral quarter with borders passing along the border of the cadastral district

-In each cadastral district - one conditional cadastral quarter with the borders passing along the border of the cadastral district [8]. 


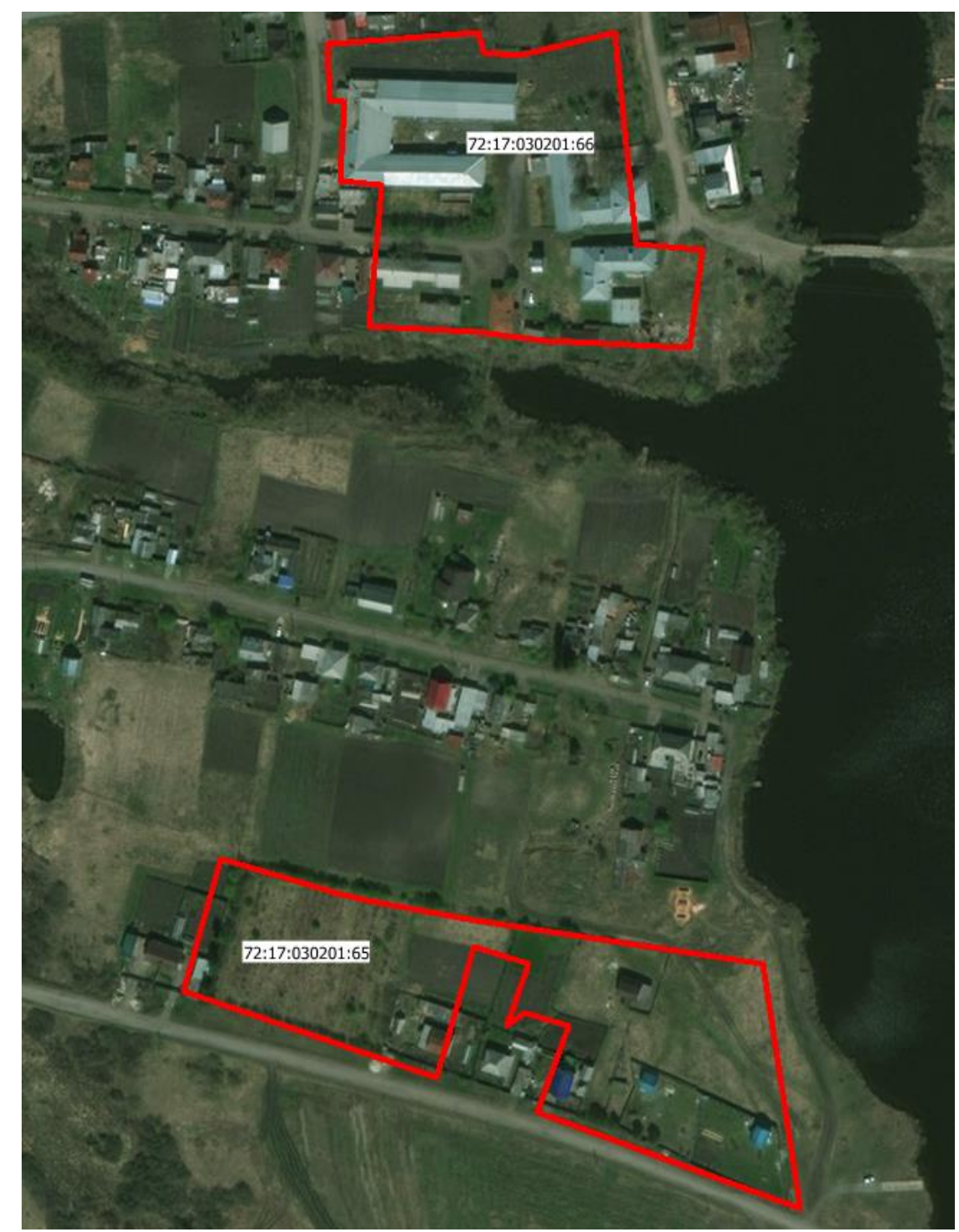

Fig. 1. Isolated plots.

To account for single land use located in several cadastral districts "All-Russian" cadastral district was created with the cadastral number « $00 »$, the border of which runs along the state border of the Russian Federation, Cadastral numbers of such single land use begin with the number «00» $[15]$.

The accounting rules for these land uses were later clarified by the order of the Federal Land Cadastre Service of Russia of August 26, 2003 № P/206 «On the organization of state cadastral registration of land plots located in the cadastral district «All-Russian».

State cadastral registration with the assignment of a separate cadastral number was carried out in relation to, as a unified land use (ULU) and in respect of all land plots included in its composition [12]. However, neither conditional nor isolated areas could not participate in civilian circulation only ULU as a single object. 
As a rule, ULU was formed in accordance with the rules related to civilian traffic, as well as organizations operating power lines and communication lines, and organizations operating linear facilities.

The Federal Law № 221 dated July 24, 2007 “On the State Real Estate Cadaster” that came into effect abolished the concept of a single land use, and introduced a new term multi-contour land plot (MCLP).

A multi-contour land plot is understood as a real estate object (land plot), the boundary of which consists of several closed contours. In this regard, the individual contours of the border of the land plot are not the land plots themselves, included in the multi-contour land plot, or its parts. At the same time, the concept of a unified land use should not be replaced by the concept of a multi-contour land plot due to the number of differences that are as follows:

1. The contours of the MCLP do not have an adjacent boundary.

2. Cadastral number is the same for all circuits that are part of the MCLP.

Thus, at present, there are two notions of types of land plots - MCLP and ULU.

To date, the formation of a unified land use is not provided by the legislation, as a result of which such land plots are unable to be created. However, previously registered land plots with similar status still exist with the appropriate mark and participate in civilian traffic [10].

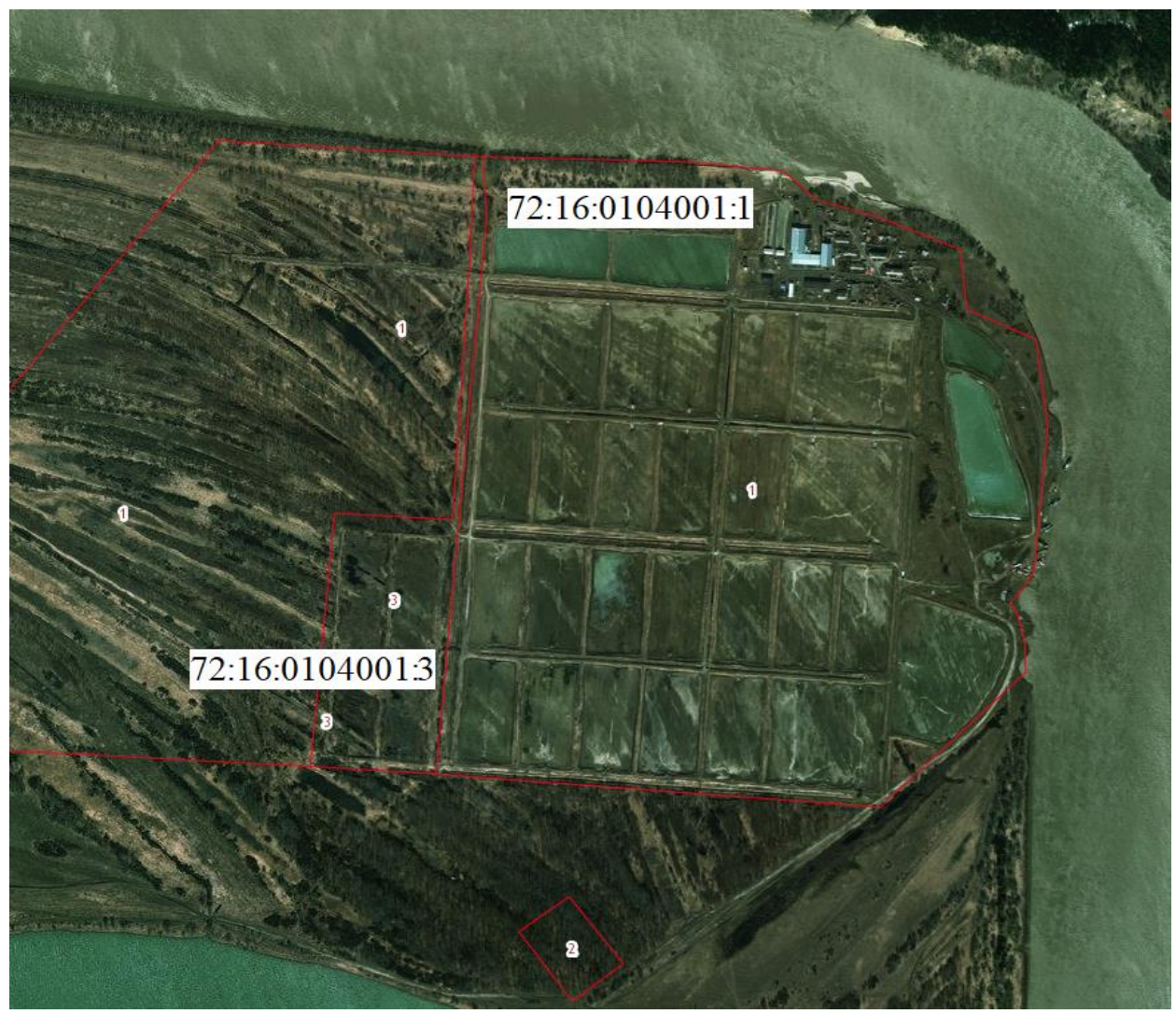

Fig. 2. Conditional plots.

\section{The procedure and conditions for cadastral registration for land representing a Unified land use}


As already noted land plots with a single land use type are no longer formed, however, information on those already recorded and so far, it is registered in the unified state register of real estate. The procedure for dealing with such real estate is defined in the letter of the Ministry of Economic Development No. 22409 IM/D23 dated December 22, 2009, which clarifies how new plots are formed from unified land use.

The following conversion methods can be applied to the previously recorded ULU:

-separation,

-apportionment with preservation of the original parcel,

-merging in case there is at least one adjacent characteristic point,

-redistribution between single land uses, or between a single land use and a land plot.

The formed land plots (including the formed multi-contour land plots) must comply with the current legislation requirements for land plots, in particular the requirements of article 11.9 of the Land Code of the Russian Federation.

According to art. 11.9 of the Land Code of the Russian Federation to the formed land plots the following requirements are imposed:

- size limits (maximum and minimum);

- the inadmissibility of the land plot to cross the boundaries of territorial zones, forest areas, forest parks (with the exception of the land plot formed for geological exploration of mineral resources, development of mineral deposits, placement of linear objects, hydraulic structures, and reservoirs, other artificial water bodies); artificial water bodies);

- the inadmissibility of land parcels formation, if it will lead to the impossibility of using the objects of real estate located on them;

- the inadmissibility of the separation, redistribution or apportionment of land plots, if they can not be used in accordance with it use permission;

- inadmissibility of land plot formation with wedging in, inclusions, broken borders, the impossibility of placing real estate and other barriers to rational use and protection from land deficiencies.

In case of noncompliance of these requirements based on Article 27 of the Federal Law No. 218-FL dated July 17, 2015, the state registrar refuses state cadastral registration of such land plot.

In any of the above listed procedures performed, the newly formed plots lose the status of a unified land use, the cadastral number of the original land plot is stored only in the case of the land plots with the original land plot preserved. 


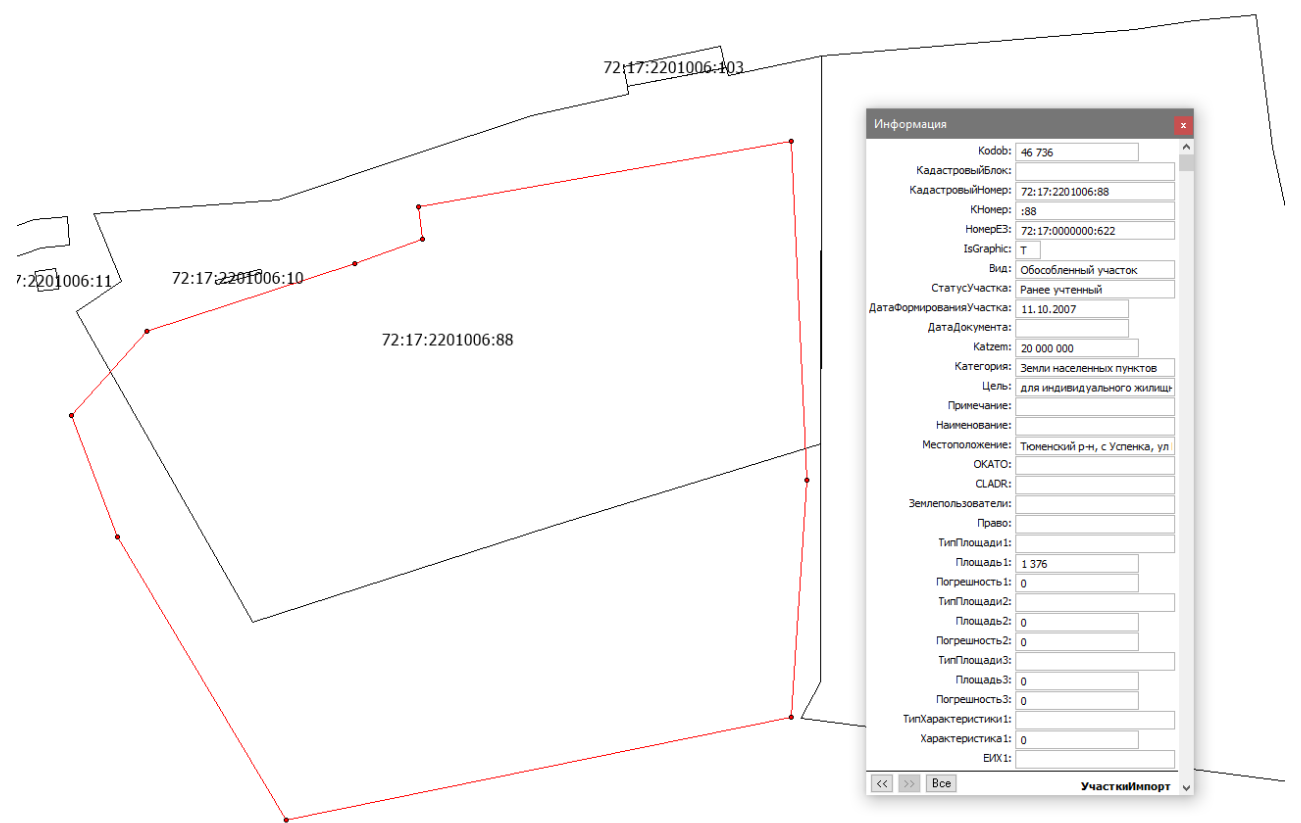

Fig. 3. Practical example.

The Code of the Russian Federation and the Federal Law of October 25, 2001 No. 137FL «On the Enactment of the Land Code of the Russian Federation» established the following cases where, as a result of the transformation of the initial land plot, one or more land plots are formed, while the initial land plot the plot is preserved in the modified boundaries:

- when dividing a land plot provided by a horticultural, gardening or dacha noncommercial association of citizens;

- when allocating a land plot from common ownership to the initial land plot;

- when dividing land owned by the state or municipal property and provided to a citizen or legal entity.

The current legislation in relation to these cases does not provide for mandatory cadastral work to clarify the location of the boundaries of the modified land plots [13]. In other cases, it is necessary to carry out the procedure for clarifying the boundaries of the ULU.

On the territory of the Russian Federation, there are land plots put on cadastral registration prior to the entry into force of the Federal Law of July 24, 2007 № 221 «On the State Real Estate Cadaster». Land plots that taken into account before the initiation of this law called previously registered. Despite the fact that these boundaries based on graphic material without land surveying. Therefore, the location of the boundaries of previously registred land plots, which include single land use, must be clarified in the process of cadastral works in order to make changes to the cadaster information, including their name and cadastral number $[17,18]$.

Such situations are possible as shown in fig. 3. Due to the fact that SLU with cadastral number 72:17:0000000:622, consisting of two conditional land plots with cadastral numbers 72:17:2201006:88 and 72:17:2201006:103, was put on cadastral registration by cartographic method without the procedure of surveying, the actual boundary does not coincide with the boundary entered in the unified state register of real estate. Which requires a procedure of boundaries clarification for the land plot. 
In the process of cadastral work to clarify the boundaries of the land plot, shown in Figure 2, a significant discrepancy between the area characteristics entered in the Unified State Register of Real Estate and the actual value obtained from geodetic measurements was revealed. Due to the fact that within the boundaries of the conditional plot with cadastral number 72:17:030201:65, newly formed land plots were formed and put on cadastral registration. The loss of areal characteristics was $20 \%$ of the total declarative area.

Clarification of boundaries or transformation of the ULU is impossible without land surveying. According to the results of the land survey procedure, a land survey plan is formed in accordance with the requirements of the Ministry of Economic Development ordered on December 8, 2015 №. 921 [16].

The boundary plan is a document that based on the cadastral plan of the relevant territory or an extract from the Unified State Register of Real Estate. Which reproduces certain information included in the Unified State Register of Real Estate (USRRE) and provides information about the land plot or land plots, or about a part or parts of the land plot, or new information necessary for entering into the Unified State Register of Real Estate.

In accordance with paragraphs 4 and 5 of the Order of the Ministry of Economic Development № 921 to the text part of the boundary plan for the formation, refinement of the land include the title page, the content and the following sections:

1) Original data

2) Information on performed measurements and calculations;

3) Information on the formed land plots and their parts;

4) Information on changed land plots;

5) Information about the correction of land plots;

6) Information on parts of land plots;

7) Information on the provision of access (passage on foot or vehicle from public lands, common land plots, common territories) to land plots formed or changed;

8) The conclusion of the cadastral engineer;

9) The act of agreeing borders location of the land plot.

The graphical part of the technical plan includes the following sections:

1) Scheme of geodetic surveys;

2) The layout of land parcels and their parts;

3) Land plots and their parts [11].

The complex of cadastral works on the preparation of the boundary plan will include the following steps:

- preparatory work;

- field work;

- cameral work;

- transfer of the land-bound plan to the customer (Fig. 4). 


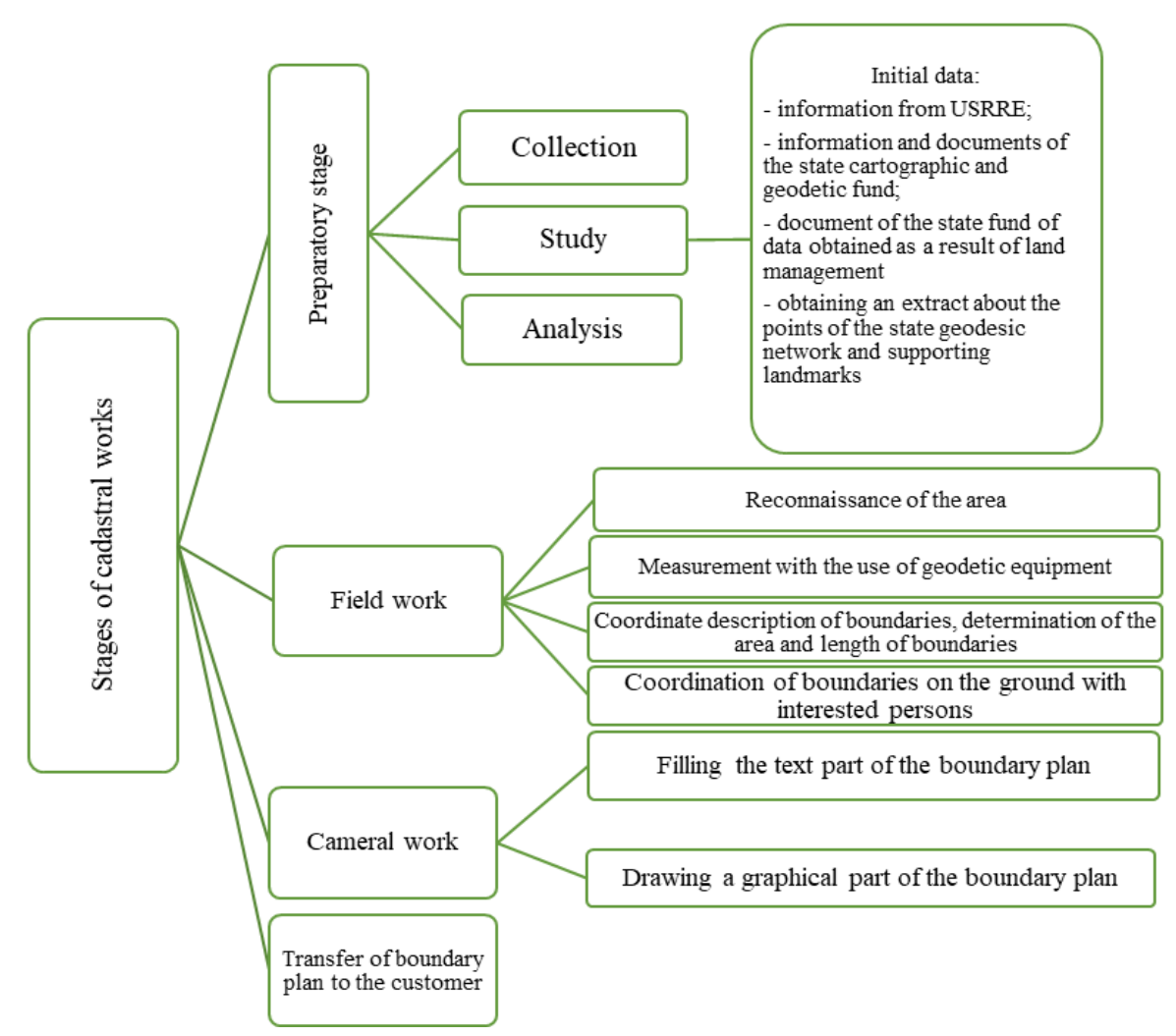

Fig. 4. Stage of work.

The main source of information in preparing the boundary plan is the cadastral plan of the territory. When conducting a survey in relation to a unified land use, the following peculiarity should be taken into account: information about the borders of the entire ULU is contained in the conditional or so-called zero cadastral quarter, and information on composite land plots is contained in the cadastral plan of the territory where they are actually located. At the same time, the work requires the conversion of the cadastral plans of the territory into the software in which the cadastral engineer works. Conversion of conditional or zero quarters takes quite some time, due to their large information content.

The most laborious of all stages is field, due to the fact that, as a rule, land plots with a single land use status are significant in terms of area characteristics, and in addition, isolated plots can be located at a considerable distance from each other.

In the case of work to clarify the boundaries of a single land use will require the preparation of coordination act of the borders location of the land plot. If a single land use consists of a sufficiently large number of separate land plots, coordination with a wide range of rightholders will be required. As a rule, with a significant number of interested parties, the approval procedure should be carried out by means of using the media. But as the court practice shows, if an interested person applies to the court with a claim to violate the land survey procedure and invalidate the results, the court takes the side of the plaintiff, but this is only if the information on the postal address or electronic address is stored in the unified state register of real estate. 


\section{Conclusion}

The concept of unified land use was introduced with the aim of involving in complex civil circulation complex composite objects of immovable property. However, the introduced type of land was not legally supported. In the by-laws, can be found only an indication of the existence of this land type, as well as an indication of actions in relation to this type. In this case, the registering authority often made a decision to refuse registration of compound land plots, rejecting the possibility of single land use existence. However, the position of the court clearly indicates that the existence of this type is possible.

Currently, land plots with the status of a single land use are not formed, but information about previously registered land plots is contained in the unified state register of immovable property. Which means that the law did not abolish the existence of this type of land. Currently, this type of land as a single land use is involved in civilian traffic, without any restrictions. It is important to take into account that registration actions can be carried out only in relation to a single land use as a whole, which means, conditional and separate plots cannot be subject to any civil-legal transaction. In this case, it is necessary to eliminate the single land use through cadastral procedures. At the same time, it is necessary to take into account a number of peculiarities in the cadastral registration procedure with concern to single land use, the explanation for which is contained in the letters of the Ministry of Economic Development of the Russian Federation.

In analysis process of boundary plans prepared for land plots bearing the status of a single land use, no difficulties or peculiarities were found for completing technical documentation, the procedures are equivalent to procedures with ordinary land plots. At the same time, when analyzing reports on the results of the analysis of the main mistakes made by cadastral engineers during the preparation of land-surveying plans, there was a lack of sufficient knowledge of cadastral engineers when working on common land uses. In particular, errors are related to the fact that cadastral engineers act in relation to separate plots, omitting information that this land plot is part of a single land use.

Moreover, in the practice of the cadastral engineer when working with single land uses, the following feature is noted - information about such real estate objects is stored in the conditional cadastral quarter, while information on conditional and separate land plots is stored in the quarter where they are located.

As noted in the letters of the Ministry of Economic Development, unified land use may cease to exist by means of cadastral procedures for the formation of land plots contained in Article 11.9 of the Land Code of the Russian Federation. At the same time, in the process of transformation, the transformation of a single land use occurs either into a so-called ordinary land plot or into a multi-contour land plot. Many authors consider common land use and multi-contour land plot to be equivalent. Undoubtedly, there are a number of significant signs indicating similarity, but at the same time, there are a number of differences.

By analogy with common land uses, the land code does not contain a clear term what is meant by a multi-contour land plot, and this is what gives rise to the multiplicity of interpretation of this term. In geodesy, a contour is an external outline of an object, that is, it is a linear measure. However, in relation to multi-contour land plots, the contour acquires the status of the area. A multi-contour land plot should be understood as a land plot provided to an individual or legal entity, formed from a set of non-adjacent contours intended to accommodate an areal (linear) object of a single functional purpose within the boundaries of one or several cadastral districts, cadastral districts or cadastral districts $[17,18]$. 
From the foregoing because of the transformations of the land parcels, such a thing as a unified land plot will end its existence. However, at the same time it is necessary to correct the concept of "multi-contour land plot".

\section{References}

1. Russian Federation Laws. Land Code of the Russian Federation № 136 (2001)

2. Russian Federation Laws. On the State Land Cadastre, Federal Law № 28 (2000)

3. Russian Federation Laws. On cadastral activity, Federal Law № 221 (2007)

4. Russian Federation Laws. On state registration of real estate, Federal Law № 218 (2015)

5. Russian Federation Laws. On the introduction of the Land Code of the Russian Federation, Federal Law № 137 (2001)

6. On approval of the Rules for cadastral division of the territory of the Russian Federation and the Rules for assigning cadastral numbers to land plots, Resolution of the Government of the Russian Federation № 660 (2000)

7. On the approval of documents of the state land cadastre № 2753 (2002)

8. On the cadastral division of the territory of the Russian Federation, Order of the Roszemkadastr № P89 (2001)

9. On the organization of state cadastral registration of land plots located in the cadastral district “All-Russian”, Order of the Roszemkadastr № P206 (2003)

10. Order Russian Economic Development № 943 (2019)

11. On approval of the form and composition of the boundary plan, requirements for its preparation, Order of the Ministry of Economic Development of Russia № 921 (2015)

12. Letter of the Ministry of Economic Development of the Russian Federation № 266IM/D23 (2009)

13. Letter of the Ministry of Economic Development of the Russian Federation № D23$671(2010)$

14. On the approval of documents of the state land cadastre, Registered in the Ministry of Justice of the Russian Federation № 2753 (2002)

15. V. Burov, Lawyer 11 (2006)

16. Yu.E.Golyakova, A.A. Kozlova, Actual problems of modern science, 9-13 (2017)

17. V.N. Klyushnichesko, I.V. Shatalov, Land Management, Cadastre and Land Monitoring, 90-95 (2014)

18. V.N. Klyushnichesko, N.V. Kaverin, Bulletin of SSUGI, 150-155 (2016) 